\title{
Laser-Raman Spectroscopy of the Iron-Transferrin-Bicarbonate Complex
}

\author{
By B. K. van Kreel, H. G. van EijK, B. Leijnse and J. H. van der MaAs \\ Department of Chemical Patbology, Medical Faculty, Rotterdam, and Department of Analytical Chemistry, University of \\ Utrecbt, Utrecht, The Netherlands
}

(Eingegangen am 15. Juli/31. August 1972)

\begin{abstract}
The iron transferrin complex was investigated by laser-Raman spectroscopy. The transferrin-Fe(III)- $\mathrm{HCO}_{3}^{-}$complex gives frequency shifts at 300 and $360 \mathrm{~cm}^{-1}$. These shifts are absent in transferrin-Fe(II)-HCO $\mathrm{HCO}_{3}^{-}$solutions under anaerobic conditions, which supports the view that the transferrin-Fe(II) is not present. The characteristic salmon colour of the transferrin-Fe(III) complexes is not coupled with the above-mentioned Raman bands.

Der Eisen-Transferrin-Komplex wurde mit der Laser-Raman-Spektroskopie untersucht. Der Transferrin-Fe(III)-HCO-Homplex zeigt Frequenzverschiebungen bei 300 und $360 \mathrm{~cm}^{-1}$. Diese Verschiebungen fehlen bei Transferrin-Fe(II)- $\mathrm{HCO}_{3}^{-}$-Lösungen unter anaeroben Bedingungen; das stützt die Ansicht, daß ein Transferrin-Fe(II)-Komplex nicht vorkommt. Die charakteristische Lachsfarbe des Transferrin-Fe(III)-Komplexes ist nicht mit dem erwähnten Raman-Banden gekoppelt.
\end{abstract}

Since it is now possible to determine iron-coordination in non-heme iron proteins using Laser-Raman spectroscopy (1), it seemed worthwhile to use this technique to collect more information about iron-transferrin complexes under different conditions. Although the discovery that transferrin - a $\beta$-globulin - binds iron was made more than 20 years ago $(2,3,4)$ a number of important questions about this protein remain unanswered. The iron-transferrin complex with the characteristic salmon colour $(465 \mathrm{~nm})$ is produced with $\mathrm{Fe}(\mathrm{II})$ as well as with $\mathrm{Fe}$ (III) under aerobic conditions. With the electron spin resonance (ESR) technique it can be demonstrated that, irrespective of the valency state of the iron used, iron exists as $\mathrm{Fe}$ (III) in the complex (5). As early as 1949 SCHADE (2) stated that oxygen was needed for the development of the salmon colour when transferrin and $\mathrm{Fe}$ (II) are brought together. There are differing theories on the significance of bicarbonate for the binding of iron to transferrin $(2,5,12,13,14)$. Since we have also investigated the binding of iron to albumin in serum (6), the present study also includes the iron-albumin complex and its behaviour with bicarbonate.

\section{Materials and Methods}

Reagents

The chemicals used were of analytical reagent grade. Human albumin was obtained from Sigma (St. Louis, USA). Human transferrin was obtained from Kabi (Stockholm, Sweden), the other chemicals are products from Merck (Darmstadt, Germany).

Preparation of proteins

Commercial human transferrin was purified as described earlier $(7,8)$.

Iron-free proteins were prepared by the method of BEZKoRovaINY

(9), fully saturated proteins were prepared by the method of RAMSAY (10). The transferrin solutions were made $1 \%(w / v)$.

\section{Determinations of iron}

After the reduction of transferrin solutions with $\mathrm{Na}_{2} \mathrm{~S}_{2} \mathrm{O}_{3}$, bathophenanthroline sulfonic acid was added and the pink complex with $\mathrm{Fe}$ (II) was measured as described previously $(13,15)$. Accuracy: for determinations of $6.0-0.6 \mu \mathrm{mol} / 1$ the standard error is $0.05 \mu \mathrm{mol} / 1$.

Preparation of the transferrin-Fe complexes under anaerobic and aerobic conditions

\section{Preparation of pure $\mathrm{N}_{2}$}

Oxygen was removed from $\mathrm{N}_{2}$ by bubbling the gas through an alkaline dithionite solution ( $150 \mathrm{~g}$ dithionite, $150 \mathrm{~g}$ indigo carmin in 112 molar $\mathrm{KOH}$ ).

The pure $\mathrm{N}_{2}$ was passed through $50 \mathrm{ml} 0.05 \mathrm{~mol} / \mathrm{l}$ phosphate buffer $\mathrm{pH}=7.4$ containing $25 \mathrm{mmol} / 1 \mathrm{HCO}_{3}^{-}$for $18 \mathrm{~h}$ at room temperature. $500 \mathrm{mg}$ apotransferrin were then added and the gas was passed for another $6 \mathrm{~h}$. This was followed by the addition of $13.2 \mu \mathrm{mol} \mathrm{FeSO}{ }_{4}+25 \mathrm{mg}$ ascorbic acid and the gas was passed for another hour. The solution remained colourless, when kept under anaerobic conditions.

A transferrin-Fe(III) complex was prepared with oxalate "instead of $\mathrm{HCO}_{3}^{-}$in aqueous solutions without phosphate and with ascorbic acid and phosphate together.

Apotransferrin was ptepared by dialysing transferrin against an acetate buffer containing EDTA as described previously $(7,9)$.

Commercial buman albumin (Sigma, 90-96\% albumin) in solutions of $50 \mathrm{~g} / 1$ was incubated with $20 \mu \mathrm{mol} / 1 \mathrm{Fe}(\mathrm{III})$ in the protein solution.

\section{Raman-spectroscopy}

Raman spectra were recorded on a Raman spectrophotometer Spectra Physics 700 with an $\mathrm{Ar}^{+}$laser, $488 \mathrm{~nm}$. Since the transferrin solutions were coloured red they were also measured on a Cary 81 with a He laser, 632.8 nm. All spectral measurements, except the anaerobic Transferin-Fe(II) solution, were made on filtered solutions (Millipore Inc. HAWP, $0.45 \mu \mathrm{m}$ ) in order to remove dust particles. Unfortunately the recording of the Raman spectra of the protein solutions was sometimes hampered due to the presence of fluorescence. It might be possible that the iron protein complexes are unstable in the laser beam as, from some measurements, it appeared that the peaks were subject to changes with time. 


\section{Results}

Spectra of the following solutions were measured, some of them are recorded in Figures 1 and 2.

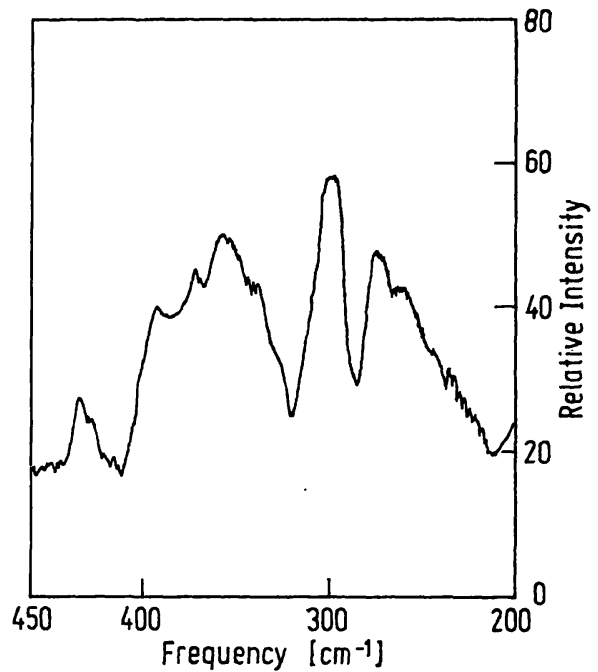

Fig. 1

The laser-Raman spectrum of transferrin- $\mathrm{Fe}(\mathrm{III})-\mathrm{HCO}_{3}^{-}$complex in aqueous solution. He laser, $632.8 \mathrm{~nm}$ spectral resolution $10^{-1} \mathrm{~cm}$. The He laser is used in order to avoid absorption

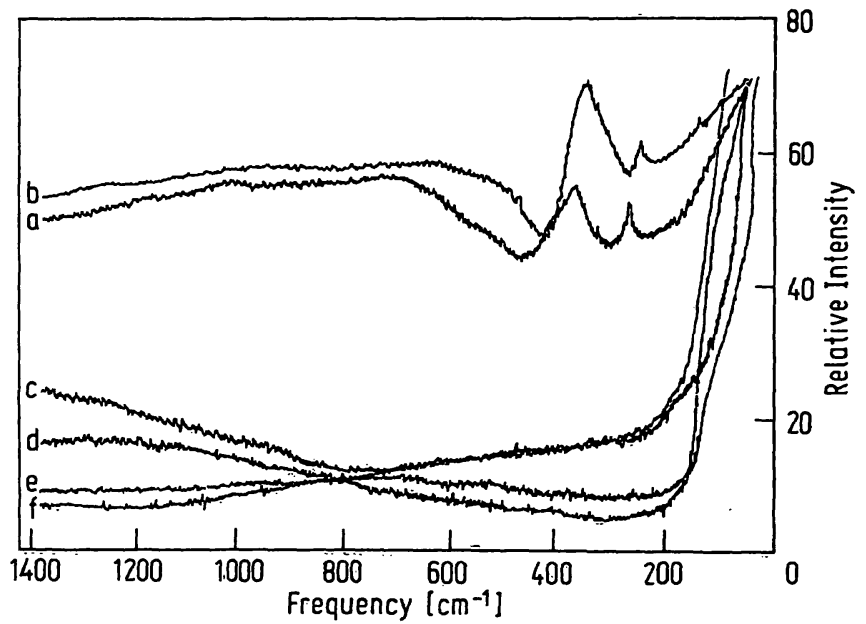

Fig. 2

The laser-Raman spectrum of different aqueous solutions $\mathrm{Ar}^{+}$laser, $488 \mathrm{~nm}$; spectral resolution $10^{-1} \mathrm{~cm}$

a) Transferrin-Fe(III)-HCOO; ; b) Albumin-Fe(III)-HCO- $\mathrm{HCO}_{3}^{-}$c) Transferrin- $\mathrm{Fe}(\mathrm{II})-\mathrm{HCO}_{3}^{-}$anaerobic; d) $\mathrm{HCO}_{3}^{-}$-ascorbic acid-phosphate- $\mathrm{Fe}$; e) Transferrin- $\mathrm{Fe}\left(\right.$ III)-oxalate; $f$ ) Transferrin- $\mathrm{Fe}$ (III)- $\mathrm{H}_{2} \mathrm{O}$

1. $0.05 \mathrm{~mol} / \mathrm{l}$ phosphate buffer $\mathrm{pH} 7.4$

2. $0.28 \mathrm{mmol} / \mathrm{l}$ ascorbic acid in $\mathrm{H}_{2} \mathrm{O}$.

3. $25 \mathrm{mmol} / \mathrm{l} \mathrm{NaHCO}_{3}$ in $\mathrm{H}_{2} \mathrm{O}$.

4. ascorbic acid $+\mathrm{HCO}_{3}^{-}$in phosphate buffer $(1+2+3)$.

5. $10 \mathrm{mmol} / 1 \mathrm{Fe}^{2+}$ in $0.01 \mathrm{~mol} / 1 \mathrm{HCl}$.

6. $10 \mathrm{mmol} / \mathrm{I} \mathrm{Fe}^{3+}$ in $0: 01 \mathrm{~mol} / \mathrm{l} \mathrm{HCi}$.

7. $10 \mathrm{mmol} / 1 \mathrm{Fe}^{3+}$ in $25 \mathrm{mmol} / 1 \mathrm{HCO}_{3}^{-}$, with or without $0.28 \mathrm{mmol} / \mathrm{l}$ ascorbic acid in phosphate buffer.

8. $25 \mathrm{mmol} / \mathrm{l} \mathrm{Na}$-oxalate in $\mathrm{H}_{2} \mathrm{O}$.

9. apotransferrin $(1 \% \mathrm{w} / \mathrm{v})$.

10. transferrin-Fe(III)-ascorbic acid, $\mathrm{HCO}_{3}^{-}$in phosphate buffer.

11. transferrin-Fe(III) in $\mathrm{H}_{2} \mathrm{O}, \mathrm{pH}=7$.

12. transferrin-Fe(III)-oxalate- $\mathrm{H}_{2} \mathrm{O}$.

13. transferrin-Fe(III)-oxalate-phosphate $\mathrm{pH}=7$.

14. transferrin-Fe(II)-ascorbic acid- $\mathrm{HCO}_{3}^{\prime}$-phosphate $\mathrm{pH}=7$, under anaerobic conditions (see methods).
15. albumin-Fe(III)-25 mmol/1 $\mathrm{HCO}_{3}^{-}$in phosphate buffer $\mathrm{pH}=7$.

16. albumin- $\mathrm{Fe}(\mathrm{II})-25 \mathrm{mmol} / \mathrm{l} \quad \mathrm{HCO}_{3}^{-}$in phosphate buffer $\mathrm{pH}=7$ under anaerobic conditions.

In order to eliminate the influence of different ions on the Raman spectra, blank solutions of buffers and proteins with or without iron were measured (solutions $1 \mathrm{t} / \mathrm{m}$ 9). These solutions did not show bands in the Raman spectra. The solution of transferrin-Fe(III)$\mathrm{HCO}_{3}-$, ascorbic acid-phosphate did show bands at 300 and $360 \mathrm{~cm}^{-1}$, probably specific for the iron- $\mathrm{HCO}_{3}^{-}$ complex. When $\mathrm{HCO}_{3}-$ in the complex was replaced by oxalate (solution No. 12 and 13) or omitted (No. 11) no bands were recorded in the Raman spectra, although these solutions give the same curve in the visible range and the same pink colour and absorption maximum at $465 \mathrm{~nm}$.

Solutions of albumin-Fe(III)- $\mathrm{HCO}_{3}-$ (No. 15) also show the same pattern as transferrin $\mathrm{Fe}-\mathrm{HCO}_{3}-$ solutions. The anaerobic transferrin-Fe(II)- $\mathrm{HCO}_{3}{ }^{-}$-ascorbic acid solution (No. 14) did not show a band.

This solution is colourless, but after exposure to the air, the red colour appears and peaks at 360 and $300 \mathrm{~cm}^{-1}$ appear, possibly indicating the formation of transferrin$\mathrm{Fe}$ (III)- $\mathrm{HCO}_{3}-$. The albumin-Fe(II)solution (No. 16) also did not show a band.

\section{Discussion}

From this investigation we conclude that the bands at 300 and $360 \mathrm{~cm}^{-1}$ can be attributed to the transferrin$\mathrm{HCO}_{3}-\mathrm{Fe}$ (III) complex. This is consistent with the observation that bicarbonate is necessary for specific iron-binding by transferrin and conalbumin, as recently noticed by PRICE and GIBSON in their paper on electron proton resonance (EPR) spectra of transferrin (11). An important result is the fact that the characteristic salmon colour of the transferrin-iron complexes is not coupled with the bands mentioned. This is clear for the colourless albumin-iron(III) complex which shows a band at 300 and $360 \mathrm{~cm}^{-1}$ and also for the coloured transferrin-oxalate solutions (Nos. $12+13$ ) which do not give frequency shifts. Raman bands are observed at 365 and $311 \mathrm{~cm}^{-1}$ for clostridial rubredoxin. So far our bands are in agreement with those found by LoNG (1). Little is known about Raman spectra of protein complexes. The meaning of these bands remains for the present obscure. From our results it is clear that the Raman bands present in the transferrin-Fe(III)- $\mathrm{HCO}_{3}-$ complex are absent in solutions of transferrin-Fe(II)$\mathrm{HCO}_{3}-$. This is in agreement with studies performed by Arsen (14) with ultraviolet difference spectrophotometry and TAVENIER (13) with sensitive analytical methods demonstrating that $\mathrm{Fe}(\mathrm{II})$ was only bound for a small part if bound at all.

\section{Acknowledgement}

We thank Dr. C. Azrona for measuring the spectra recorded in Figure 1 on the Cary 81 spectrophotometer. 


\section{References}

1. Long, T. V. \& Loehr, T. M. (1970), J. Amer. Chem. Soc. 92, 6384-6386. - 2. Schade, A. L., Reinhart, R. W. \& Levie, H. (1949), Arch. Biochem. Biophys. 20, 170-172. - 3. Holmberg, C. G. \& Laureli, C. B. (1947), Acta Chem. Scand. 1, 944-950. - 4. Schade, A. L. \& Caroline, L. (1946), Science 104, 340-341. - 5. Aasa, R., Malmström, B. G., Saltmann, P. \& VäNNGaRd, T. (1963), Biochim. Biophys. Acta 75, 203-222. 6. van der Heul, C., van Eijk, H. G., Wiltink, W. F. \& Leijnse, B. (1972), Clin. Chim. Acta 38, 347-353. - 7. van EijK, H. G. \& Leijnse, B. (1968), Biochim. Biophys. Acta 160, 126-128. - 8. van EIJK, H. G., van Dijk, J. P., van Noort, W. L., Liejnse, B. \& Monfoort, C. H. (1972), Scand. J. Hae- matology 9, 267-271. - 9. LINE, W.F., GROHLìch, D. \& Bezkorovainy, A. (1967), Biochemistry 6, 3393-3402. 10. Ramsay, W. N. M. (1957), Clin. Chim. Acta 2, 221-226. 11. PrICE, E. M. \& Grbson, J.F. (1972), Biochem. Biophys. Res. Commun. 46, 646-651. - 12. WARNER, R. C. \& Weber, I. (1953), J. Amer. Chem. Soc. 75, 5094-5101. - 13. Tavenier, P. (1971), Een onderzoek naar het niet aan transferrine gebonden ijzer in plasma. Acad. Proefschrift, Medical Faculty Rotterdam, The Netherlands. - 14. Gaber, B. P'. \& Aisen, Ph. (1970), Biochim. Biophys. Acta 221, 228-233. - 15. TrendLER, P. J. (1956), J. Clin. Pathol. 9, 170-172.
Dr. H. G. van Eijk Chemical Pathology Medical Faculty Rotterdam P. O. Box 1738 Rotterdam

The Netherlands 